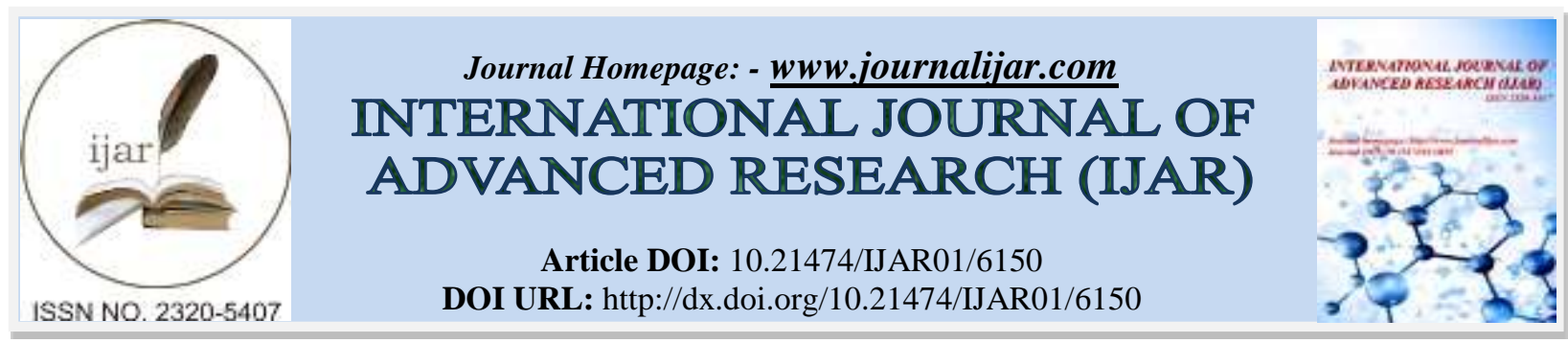

RESEARCH ARTICLE

\title{
INFORMATION REQUREMENTS OF RURAL PEOPLE IN KERALA AND RELEVENCE OF COMMUNITY INFORMATION CENTRES.
}

Dr. SUJA K. Librarian (UGC).

Kerala Kalamandalam (to be Deemed University) for Art and Culture. Thrissur. Dist. Kerala.

\section{Manuscript Info}

Manuscript History

Received: 23 October 2017

Final Accepted: 25 November 2017

Published: December 2017

Key words:-

Information, Rural Development,

Community Information Centres.

\section{Abstract}

Through a questionnaire survey the study analyses the information requirements of the rural people in Kerala and relevance of community information centres in each panchayat. The statistical techniques used for analysis of the data were arithmetic mean and standard deviation. The study indicates that the rural people in Kerala are enjoying most of the information sources available in the present society and mass media is the most satisfied information source for them. According to the study the rural people showed their deep interest in the concept of community information centres in their panchayat. The article concludes that in order to meet all the information requirements of the village people a well organized information centre in rural areas of Kerala is essential.

Copy Right, IJAR, 2017,. All rights reserved.

\section{Introduction:-}

The Indian society is predominantly a rural society. It is characterized by a variety of structural disadvantages and disparities like illiteracy, malnutrition, poverty, and caste complications exist in Indian society. Consequently the information needs of rural areas relating to the basic needs, economic, educational or recreational needs, are not being properly assessed or met.

The basic needs of rural people include facilities for health care, water supply, shelter and other amenities. These are desired ideally right at the door steps of households. Economic needs depend on the information on how to produce better crops, where to sell the products and other market information. Educational needs mainly center around provision of affordable text books, teaching aids for education and continuing education. Finally, the recreational needs fulfil the much needed diversion from the routine and to continue with traditional art forms. Creation of sports facilitates and organization of cultural activities is grouped under these needs. Besides these, the information needs arise and the rural people look for, where to find what, who is who in their locality, and services in the village for utilities available in the nearest town (Raju, 2002) ${ }^{1}$

Information is an important resource and is essential for the progress of an individual and of a nation ${ }^{2}$. Information transfer and information revolution through which culture change, and socio-economic development of a nation is possible. Information is the basic need of life, which helps in fulfillment of other needs such as food, shelter etc. without information the growth and development of any community, is impossible. Information needs of the rural people are different from the urban people. In the present study the investigator tries to analyse and identifies the information needs of the rural people from different perspectives and relevance of community information centres in each panchayats of Kerala state. 


\section{Review of related literature:-}

There are numerous studies going on the information needs and relevance of community information centre in villages of India. This review presents some of studies regarding necessity of community information centres.

Boonalia ${ }^{3}$ in his article states that the need of rural community centers at the villages and the major functions of the rural community centers can be recognized as to provide scope for education, information and recreation to the rural masses. The centers will play a vital role in their social, cultural, physical, mental and economic development. The author hardly stresses that rural community centers with multi-dimensional activities will be the forum for building up an enlightened well informed, cultured and progressive society in the country.

Kumaresan and Chitra ${ }^{4}$ have conducted a study to assess the need for rural information centres in the villages of Tamil Nadu. There are agricultural information centres in many villages of Tamil Nadu that disseminate vital information to the farmers about the crop, manure, and other related details. However, villagers who are dependent on professions other than agriculture for livelihood have no such facility that fulfils their information requirements. Twenty villages in the state of Tamil Nadu have been studied to asses the need for rural information centres. Further, the concept of rural information centers has been suggested. The Rural information centres aim to meet all information requirements at the village level.

Bajpai and Upadhyay ${ }^{5}$ in their paper suggest that information is very essential for national development, without right and timely information; no progress is possible for any kind of work. The policy makers should recognize the library as an agency of vital importance in providing information, which is an essential ingredient to the welfare and development of the tribal community. Information is collected from published and unpublished sources and organized as files, directories, leaflets, pamphlets, displays, and exhibits, and audio- visual aids. The information is served as advice counselling support practical aid, referral services etc. Majority of people live in rural places. Thus development in rural areas is the urgency of the time for overall development of the nation. Therefore rural development information networks are the backbone in this regard.

Sharma has conducted a study on information needs and sharing pattern among rural women in Madhya Pradesh. The study is based on the 145 rural women respondents of Gwalior districts of Madhya Pradesh. The main objective of the study is the examination of information needs of the rural women community under study. It also intended to find out the nature, sources and purpose of information, which they required. And try to analyzing the time and money spent for gathering most reliable sources of information. It consists of review of related literature and scope of the study. Analysis of data reveals that majority of the women are getting information through television (93.7\%), 35.17 percent of the women under study are consulting religious leaders for their information needs. Study reveals that 81.37 percent respondents share information with their family members. Field and well are the most common places for sharing information, all women are familiar with telephone while only 33.79 percent women used telephone facility, and 2.75 percent rural women are familiar with internet.

\section{Objectives of the study:-}

To find out the information needs of rural people and significance of a community information centre in each panchayats in Kerala

\section{Methodology:-}

It is not practical to study the whole population to arrive at generalisations though the result of the research is to have universal application. The process of sampling makes it possible to draw valid inferences or generalisations on the basis of careful observation of variables within a relatively small proportion of population.

As per 2011 provisional population figures, rural population in Kerala is 17,455,506. (Census report, 2011) ${ }^{7}$. This is too large in size to collect data from the entire population is very difficult. Hence the investigator selected a representative part of this population to conduct the study. The state consists of 14 districts including 978 panchayats. Since the study should be completed within a short span of time and it is very difficult to cover all the panchayats, the investigator had been used a stratified random sampling method for the selection of the districts and panchayats for the study.

The investigator has selected three districts from the fourteen districts of Kerala state, one from the northern region, Kasaragod; one from the middle region, Thrissur; and last and third one from the southernmost region, 
Thiruvananthapuram. On the basis of classificatory variables the investigator has collected data from four panchayats from each district, having higher and lower distribution of population and literacy rate. Hence the total number of panchayats taken for study is twelve $(4 \times 3=12)$.

The population consists of rural people belonging to different panchayats with different characteristics. In order to get samples from all groups, the investigator has grouped the users into four, based on the status of living. The groups thus obtained are professionals, students, housewives and labours.

The investigator personally visited all the twelve panchayats and collected data by providing a structured questionnaire. Data pertaining to classificatory and study variables were consolidated separately by using spreadsheet package 'Excel'. The data were then subjected to further statistical treatment by using the statistical package 'Statistical Package for Social Sciences' (SPSS).

\section{Information needs of rural community in Kerala:-}

Information being power, its proper dissemination makes a society egalitarian. An open house information system is a powerful tool in the hands of the people leading to greater transparency, accountability and efficiency at all levels. The rural community needs information for survival rather than information for research ${ }^{8}$. In the present article deals with the information needs of rural people in Kerala in different perspectives

\section{Source of Daily Information:-}

Information is one the fundamental need of human being. The rural people under study are requested to make known the source which they are using to fulfil their daily information requirement from the five options. The details of the data analysis are given in the Table 1.

Table 1:- Source of Daily Information

\begin{tabular}{|c|c|c|c|c|c|}
\hline $\begin{array}{l}\text { Sources of } \\
\text { information }\end{array}$ & Professionals & Students & Housewives & Labours & Total \\
\hline Newspapers & $\begin{array}{c}90 \\
44.8 \%\end{array}$ & $\begin{array}{c}73 \\
35.4 \%\end{array}$ & $\begin{array}{c}35 \\
17.2 \%\end{array}$ & $\begin{array}{c}69 \\
34.5 \%\end{array}$ & $\begin{array}{c}267 \\
33 \%\end{array}$ \\
\hline Television & $\begin{array}{c}51 \\
25.4 \%\end{array}$ & $\begin{array}{c}48 \\
23.3 \%\end{array}$ & $\begin{array}{c}62 \\
30.5 \%\end{array}$ & $\begin{array}{c}52 \\
26.0 \%\end{array}$ & $\begin{array}{c}213 \\
26.3 \%\end{array}$ \\
\hline Radio & $\begin{array}{c}25 \\
12.4 \%\end{array}$ & $\begin{array}{c}28 \\
13.6 \%\end{array}$ & $\begin{array}{c}47 \\
23.2 \%\end{array}$ & $\begin{array}{c}47 \\
23.5 \%\end{array}$ & $\begin{array}{c}147 \\
18.2 \%\end{array}$ \\
\hline Library & $\begin{array}{c}15 \\
7.5 \%\end{array}$ & $\begin{array}{c}20 \\
9.7 \%\end{array}$ & $\begin{array}{c}11 \\
5.4 \%\end{array}$ & $\begin{array}{c}11 \\
5.5 \%\end{array}$ & $\begin{array}{c}57 \\
07.4 \%\end{array}$ \\
\hline Friends & $\begin{array}{c}20 \\
9.9 \%\end{array}$ & $\begin{array}{c}37 \\
18 \%\end{array}$ & $\begin{array}{c}48 \\
23.7 \%\end{array}$ & $\begin{array}{c}21 \\
10.5 \%\end{array}$ & $\begin{array}{c}126 \\
15.5 \%\end{array}$ \\
\hline Total & 201 & 206 & 203 & 200 & 810 \\
\hline
\end{tabular}

The Table 1 makes it clear that a large portion (33\%) of the rural people under study is using newspapers as a source for information relating to the daily happenings in their locality. Television $(26.3 \%)$ and radio (18.2\%) are the next preferred media used for collecting information. It can be seen from the Table 1 that one of the important medium for collecting information by the rural people, is friends or neighbors (15.5\%). There is a small per cent of (7\%) rural people under study visiting the library to fulfill their daily information needs. 


\section{Figure 1:-}

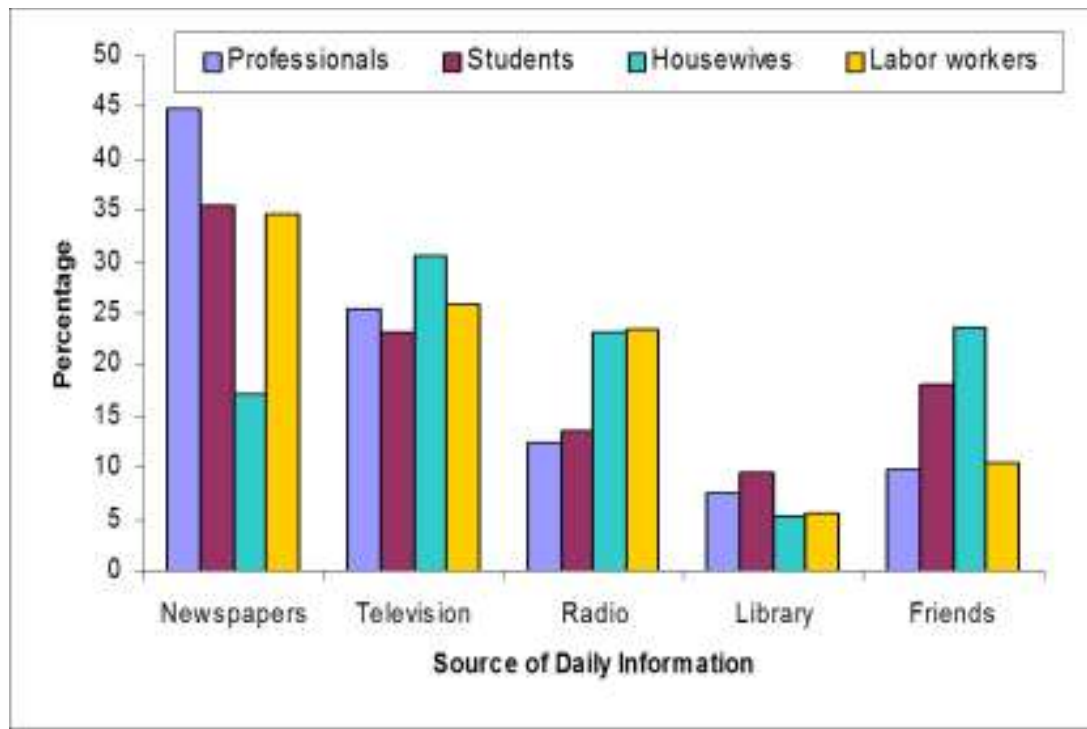

\section{Source of Daly Information:-}

The category wise analysis of the data shown in the Table 1 and Figure 1 reveals that greater part of the professionals $(44.8 \%)$; students $(35.4 \%)$ and labours $(34.5 \%)$ are reading newspapers to know daily events taking place in the society. On the other hand 30.5 per cent of the housewives vouch that they prefer television to collect daily news.

The Table 1 and Figure 1 show that even though the technology has developed hitherto, newspapers are the most dominant source for information, in rural Kerala.

The details of the gender wise analysis of the data related with the sources of information in the daily life of the rural people are given in the Table 2 .

Table 2:- Gender wise analysis-Source of daily information

\begin{tabular}{|l|c|c|c|}
\hline \multicolumn{1}{|c|}{ Sources of information } & Female & Male & Total \\
\hline Newspapers & 101 & 166 & 267 \\
& $22.2 \%$ & $46.6 \%$ & $33 \%$ \\
\hline Television & 129 & 84 & 213 \\
& $28.4 \%$ & $23.6 \%$ & $26.3 \%$ \\
\hline Radio & 98 & 49 & 147 \\
& $21.6 \%$ & $13.8 \%$ & $57 \%$ \\
\hline Friends & 17 & 40 & $07 \%$ \\
& $3.7 \%$ & $11.2 \%$ & 126 \\
\hline Total & 109 & 17 & $15.5 \%$ \\
\hline
\end{tabular}

The Table 2 shows that greater portion of the male (46.6\%) respondents are using newspapers and female (28.4\%) are watching television for fulfilling their daily information needs.

\section{Source for Particular Information:-}

If a rural citizen wants to get particular information on a particular topic, what is the method they obtain? The people under study were requested to specify their answers and it is depicted in the Table 3. 
Table 3:- Source for Particular Information

\begin{tabular}{|c|c|c|c|c|c|}
\hline $\begin{array}{l}\text { Source of } \\
\text { particular } \\
\text { information }\end{array}$ & Professionals & Students & Housewives & Labours & Total \\
\hline Depend friends & $\begin{array}{c}94 \\
46.8 \%\end{array}$ & $\begin{array}{c}58 \\
28.2 \%\end{array}$ & $\begin{array}{c}112 \\
55.2 \%\end{array}$ & $\begin{array}{c}98 \\
49 \%\end{array}$ & $\begin{array}{c}362 \\
44.7 \%\end{array}$ \\
\hline Approach library & $\begin{array}{c}77 \\
38.3 \%\end{array}$ & $\begin{array}{c}68 \\
33 \%\end{array}$ & $\begin{array}{c}23 \\
11.3 \%\end{array}$ & $\begin{array}{c}45 \\
22.5 \%\end{array}$ & $\begin{array}{c}213 \\
26.3 \%\end{array}$ \\
\hline Depend experts & $\begin{array}{c}30 \\
14.9 \%\end{array}$ & $\begin{array}{c}80 \\
38.8 \%\end{array}$ & $\begin{array}{c}68 \\
33.5 \%\end{array}$ & $\begin{array}{c}57 \\
28.5 \%\end{array}$ & $\begin{array}{c}235 \\
29 \%\end{array}$ \\
\hline Total & 201 & 206 & 203 & 200 & 810 \\
\hline
\end{tabular}

It can be seen from the Table 3 that greater part of the professionals (46.8\%), housewives (55.2\%) and labours $(49 \%)$ are depending on friends when they are in need of a particular piece of information. But students (38.8\%) mainly approach the experts known to them, to solve their problem. The Table 3 also reveals that 38.3 per cent of the professionals and 33 per cent of the students approach library to search for particular piece of information. However, a small number (11.3\%) of the housewives and labours $(22.5 \%)$ visit library when they are in need of particular information.

Although Kerala people are said to be a society of well informed people, the rural people are still ignorant of the technological developments in the country. Majority of the people are approaching friends to gain their information, on a particular topic.

\section{Major Sources of Information:-}

The rural community is enjoying most of the information sources available in the present society. Since information is acting as an inevitable ingredient in the day to day activities of human being, the investigator asked to mention the most preferable satisfied source of information.

Table 4:- Major Sources of Information

\begin{tabular}{|l|c|c|c|c|c|}
\hline Information source & Professionals & Students & Housewives & Labours & Total \\
\hline Training/ & 87 & 44 & 35 & 21 & 187 \\
Workshops & $43.3 \%$ & $21.4 \%$ & $17.2 \%$ & $10.5 \%$ & $23.1 \%$ \\
\hline Mass media & 158 & 165 & 148 & 128 & 599 \\
& $78.6 \%$ & $80.1 \%$ & $72.9 \%$ & $64.0 \%$ & $73.9 \%$ \\
\hline Dictionaries/ & 54 & 60 & 64 & 58 & 236 \\
Encyclopedias & $26.9 \%$ & $29.1 \%$ & $31.5 \%$ & $29.0 \%$ & $29.1 \%$ \\
\hline Handbooks/Manuals & 74 & 98 & 71 & 48 & 291 \\
& $36.8 \%$ & $47.6 \%$ & $35.0 \%$ & $24.0 \%$ & $35.9 \%$ \\
\hline
\end{tabular}

From the analysis of the Table 4 it can be inferred that mass media (73.9\%) is the major information source among the rural community. Mass media includes Print (Newspapers, Books, and Magazines), Radio, Television, Cable TV, Telecommunications, and Internet. There are 43.28 per cent of professionals and 21.4 per cent of the students participating in trainings and workshops. In the case of 17.24 per cent of the housewives and 10.5 per cent of labours are participating in training and workshops for acquiring information. Professionals and students have several chances to participate in various workshops and seminars. Housewives are participating in seminars conducted by kudumbasree and other women organizations. It is interesting to note that reference sources like dictionaries/encyclopedias $(29.1 \%)$ and handbooks/ manuals $(35.9 \%)$ are also preferred by the rural people under study.

Table 4 reveals that mass media is the greatest information source for the rural community. Radio and television are also broadcasting Rural Development programmes from which rural people were aware of practical life and helps to decisions for their development.

\section{Visit to Library:-}

Libraries are, by their very nature, the centres for the spread of knowledge and information and as such, they can play a very vital role in the spread of Rural Development in Kerala. In this regard the investigator wants to know the status of library visit among the rural people. 
Table 5:- Visit to Library.

\begin{tabular}{|c|c|c|c|c|c|}
\hline Library visit & Professionals & Students & Housewives & Labours & Total \\
\hline Yes & 117 & 194 & 23 & 45 & 379 \\
& $58.2 \%$ & $94.2 \%$ & $11.3 \%$ & 180 & $46.8 \%$ \\
\hline No & 84 & 12 & $88.7 \%$ & $77.5 \%$ & 431 \\
& $41.8 \%$ & $05.8 \%$ & 203 & 200 & $83.2 \%$ \\
\hline Total & 201 & 206 & & 810 \\
\hline
\end{tabular}

Category wise analysis of the data given in the Table 5 makes it clear that depending on the field of work a large majority of students $(94.2 \%)$ and professionals $(58.2 \%)$ in rural areas are visiting library. On the other hand a large majority of the $(88.7 \%$ ) housewives and labours $(77.5 \%)$ affirmed that they do not visit the library.

General analysis of the data presented in the Table 5 shows that majority (53.2\%) of the respondents are not visiting library. Gender wise analysis of the data regarding the library visit among the rural people is given in the Table 6 .

Table 6:- Gender wise analysis of Visit to Library

\begin{tabular}{|l|c|c|c|}
\hline Library visit & Female & Male & Total \\
\hline Yes & 153 & 226 & 379 \\
& $33.7 \%$ & $63.5 \%$ & $46.8 \%$ \\
\hline No & 301 & 130 & 431 \\
& $66.3 \%$ & $36.5 \%$ & $53.2 \%$ \\
\hline Total & 454 & 356 & 810 \\
\hline
\end{tabular}

Gender wise analysis of the data presented in the Table 6 shows that majority (63.2\%) of the male respondents visit the library for seeking various kinds of information. At the same time most $(66.3 \%)$ of the female respondents are not visiting the library.

\section{Materials Preferring for Reading:-}

A library is to help village children and adult in understanding the principles of basic education and keeping fresh their knowledge. It can also supply the reading materials related to various fields of Rural Development. The rural people under study are requested to reveal their most interesting reading material from the library.

Table 7:- Materials Preferring for Reading

\begin{tabular}{|c|c|c|c|c|c|}
\hline $\begin{array}{l}\text { Preferred reading } \\
\text { materials }\end{array}$ & Professionals & Students & Housewives & Labours & Total \\
\hline Newspapers & $\begin{array}{c}111 \\
94.9 \%\end{array}$ & $\begin{array}{c}154 \\
79.4 \%\end{array}$ & $\begin{array}{c}15 \\
65.2 \%\end{array}$ & $\begin{array}{c}40 \\
88.9 \%\end{array}$ & $\begin{array}{c}280 \\
73.9 \%\end{array}$ \\
\hline Subject materials & $\begin{array}{c}66 \\
56.4 \%\end{array}$ & $\begin{array}{c}118 \\
60.8 \%\end{array}$ & $\begin{array}{c}5 \\
21.7 \%\end{array}$ & $\begin{array}{c}32 \\
71.1 \%\end{array}$ & $\begin{array}{c}191 \\
50.4 \%\end{array}$ \\
\hline Literature & $\begin{array}{c}84 \\
71.8 \% \\
\end{array}$ & $\begin{array}{c}121 \\
62.4 \% \\
\end{array}$ & $\begin{array}{c}18 \\
78.3 \% \\
\end{array}$ & $\begin{array}{c}23 \\
51.1 \% \\
\end{array}$ & $\begin{array}{c}215 \\
56.7 \% \\
\end{array}$ \\
\hline Current affaires & $\begin{array}{c}98 \\
83.8 \% \\
\end{array}$ & $\begin{array}{c}146 \\
75.3 \% \\
\end{array}$ & $\begin{array}{c}12 \\
52.2 \% \\
\end{array}$ & $\begin{array}{c}37 \\
82.2 \% \\
\end{array}$ & $\begin{array}{c}256 \\
67.5 \% \\
\end{array}$ \\
\hline Total & 117 & 194 & 23 & 45 & 379 \\
\hline
\end{tabular}

From the analysis of the Table 7 , it can be understood that majority $(73.9 \%)$ of the respondents prefer to read various newspapers available in different languages in the library. It includes 94.9 per cent of professionals, 88.9 per cent of labour sand 79.4 per cent of students. Professional's reading interests differ from that of housewives and labours. It shows that large majority $(78.3 \%)$ of the housewives under study prefer to read literature than any other material. All the rural community except housewives give second preference to collecting current information from the library, it consists of 83.8 per cent of professionals, 75.3 per cent of students and 82.2 per cent of labours. The housewives under study give preference in the order of newspapers (65.2\%), current affairs $(52.2 \%)$ and subject materials $(21.7 \%)$.

The general analysis of the Table 7 shows that the respondents under study give preference in the order of newspapers $(73.9 \%)$, current affairs $(67.5 \%)$, literature $(56.7 \%)$, and finally subject materials $(50.4 \%)$. 
It must be clearly understood that the need and demand for information by the rural people are directly related to their day to day activities. This kind of information can only be supplied by a Community Information Centre.

\section{Need for Current Information:-}

The rural people need support and assistance for a better life. To help and assist in upgrading the economic conditions of the rural people and in raising their living standards, a library can help in this regard. Here the investigator tries to identify the requirements of current information among the rural people under study.

Table 8:- Need for Current Information

\begin{tabular}{|l|c|c|c|c|c|}
\hline $\begin{array}{l}\text { Need for current } \\
\text { information }\end{array}$ & Professionals & Students & Housewives & Labours & Total \\
\hline Required & 120 & 120 & 98 & 108 & 446 \\
& $59.7 \%$ & $58.2 \%$ & $48.3 \%$ & $54 \%$ & $55.1 \%$ \\
\hline Not required & 81 & 86 & 105 & $46 \%$ & 364 \\
& $40.3 \%$ & $41.8 \%$ & $51.7 \%$ & 200 & $84.9 \%$ \\
\hline Total & 201 & 206 & 203 & & 810 \\
\hline
\end{tabular}

According to the Table 8 a large number $(55.1 \%)$ of the rural people under study are inquisitive to know the latest information on various things. It includes 59.7 per cent of professionals, 58.2 per cent of students and 54 per cent of labours. But majority of the $(51.7 \%)$ housewives agreed that they didn't need latest information on a particular topic.

Gender wise analysis of the current information requirements of the rural community under study are examined in the Table 9.

Table 9:- Gender wise Analysis of Need for Current Information

\begin{tabular}{|l|c|c|c|}
\hline $\begin{array}{c}\text { Need for current } \\
\text { information }\end{array}$ & Female & Male & Total \\
\hline Required & 182 & 264 & 446 \\
& $40.1 \%$ & $74.2 \%$ & $55.1 \%$ \\
\hline Not required & 272 & 92 & 364 \\
& $59.9 \%$ & $25.8 \%$ & $44.9 \%$ \\
\hline Total & 454 & 356 & 810 \\
\hline
\end{tabular}

The gender wise analysis of the data presented in the Table 8 shows that men $(74.2 \%)$ in rural Kerala mostly required current information on various topic than the female (40.2\%) community under study.

The reason for it is the scope of information needed by men is vast than that of women. Most of the women concentrated on a single thing and try to be master on that. But the gents try to understand and gain information on several things at a time. So the information requirements of the men cannot be fulfilled by the library itself.

\section{Need for Retrospective Information:-}

The rural community should know about history of the nation, biography of famous people, culture, government policies and plans. By this type of information, rural people can understand about many famous people's contribution which may be helpful for their every day life. They can also analyse the plans which are good for them. The researcher tries to identify the retrospective information needs of the people under study.

Table 9:- Need for Retrospective Information

\begin{tabular}{|l|c|c|c|c|c|}
\hline $\begin{array}{l}\text { Need for } \\
\text { retrospective } \\
\text { information }\end{array}$ & Professionals & Students & Housewives & Labours & Total \\
\hline Required & 96 & 105 & 150 & 104 & 455 \\
& $47.8 \%$ & $51.0 \%$ & $73.9 \%$ & $52 \%$ & $56.2 \%$ \\
\hline Not required & 105 & 101 & 53 & 96 & 355 \\
& $52.2 \%$ & $49.0 \%$ & $26.1 \%$ & $48 \%$ & $43.8 \%$ \\
\hline Total & 201 & 206 & 203 & 200 & 810 \\
\hline
\end{tabular}


The category wise analysis of the data shown in the Table 9 reveals that housewives (73.9\%) require retrospective information on various topics than any other categories. The general analysis of the Table 9 shows that a large percent of $(56.2 \%)$ the rural people under study have answered that they needed retrospective information and the remaining $(43.8 \%)$ have a negative view on this aspect.

\section{Information Sources for Getting Your Area of Working:-}

Since the people under study belong to various categories, the information requirements of them are also different (Educational/ Agriculture/Small scale industries/ Business/Animal Husbandry etc). The investigator tries to examine the sources from where the rural people acquiring their area of working.

Table 10:- Information Sources for Getting Your Area of Working

\begin{tabular}{|c|c|c|c|c|c|}
\hline $\begin{array}{c}\text { Information } \\
\text { source }\end{array}$ & Professionals & Students & Housewives & Labours & Total \\
\hline News papers & $\begin{array}{c}104 \\
51.7 \% \\
\end{array}$ & $\begin{array}{c}119 \\
57.8 \%\end{array}$ & $\begin{array}{c}74 \\
36.4 \%\end{array}$ & $\begin{array}{c}90 \\
45 \%\end{array}$ & $\begin{array}{c}387 \\
47.8 \%\end{array}$ \\
\hline $\begin{array}{l}\text { Community } \\
\text { information } \\
\text { centers }\end{array}$ & - & - & - & - & - \\
\hline Radio & $\begin{array}{c}58 \\
28.8 \%\end{array}$ & $\begin{array}{c}49 \\
23.7 \%\end{array}$ & $\begin{array}{c}98 \\
48.2 \%\end{array}$ & $\begin{array}{c}99 \\
49.5 \%\end{array}$ & $\begin{array}{c}304 \\
37.5 \%\end{array}$ \\
\hline Television & $\begin{array}{c}99 \\
49.2 \%\end{array}$ & $\begin{array}{c}105 \\
50.9 \%\end{array}$ & $\begin{array}{c}63 \\
31.0 \%\end{array}$ & $\begin{array}{c}94 \\
47 \%\end{array}$ & $\begin{array}{c}361 \\
44.6 \%\end{array}$ \\
\hline Panchayat offices & $\begin{array}{c}42 \\
20.9 \%\end{array}$ & $\begin{array}{c}41 \\
19.9 \%\end{array}$ & $\begin{array}{c}90 \\
44.3 \%\end{array}$ & $\begin{array}{c}108 \\
54 \%\end{array}$ & $\begin{array}{c}281 \\
34.7 \%\end{array}$ \\
\hline Total & 201 & 206 & 203 & 200 & 810 \\
\hline
\end{tabular}

From the analysis of the Table 10 it can be inferred that the respondents mainly depend on newspapers (47.8\%) and television (44.6\%) for accessing information regarding their area of work. The category wise analysis shows that housewives (48.2\%) listen to radio more than the other category. However labours visit panchayat offices (54\%) for collecting information regarding their area of work. Professionals and students prefer newspapers and television for accessing information related to their official and academic purposes.

\section{Areas Having Difficulties in Acquiring Information:-}

Since the areas under study are typically rural places the people cannot easily access all the required information in time. The investigator tries to identify the areas having difficulties in acquiring correct information.

Table 11:- Areas Having Difficulties in Acquiring Information

\begin{tabular}{|c|c|c|c|c|c|}
\hline $\begin{array}{l}\text { Difficult } \\
\text { Areas }\end{array}$ & Professionals & Students & Housewives & Labours & Total \\
\hline Bus/train time & $\begin{array}{c}70 \\
34.8 \% \\
\end{array}$ & $\begin{array}{c}62 \\
30.1 \% \\
\end{array}$ & $\begin{array}{c}77 \\
37.9 \% \\
\end{array}$ & $\begin{array}{c}86 \\
43 \% \\
\end{array}$ & $\begin{array}{c}295 \\
36.4 \% \\
\end{array}$ \\
\hline $\begin{array}{l}\text { Agencies for going } \\
\text { abroad }\end{array}$ & $\begin{array}{c}63 \\
31.3 \% \\
\end{array}$ & $\begin{array}{c}78 \\
37.9 \% \\
\end{array}$ & $\begin{array}{c}85 \\
41.9 \% \\
\end{array}$ & $\begin{array}{c}93 \\
46.5 \% \\
\end{array}$ & $\begin{array}{c}319 \\
39.4 \% \\
\end{array}$ \\
\hline $\begin{array}{l}\text { Rural development } \\
\text { programmes }\end{array}$ & $\begin{array}{c}50 \\
24.9 \% \\
\end{array}$ & $\begin{array}{c}88 \\
42.7 \% \\
\end{array}$ & $\begin{array}{c}66 \\
32.5 \% \\
\end{array}$ & $\begin{array}{c}78 \\
39 \% \\
\end{array}$ & $\begin{array}{c}282 \\
34.8 \% \\
\end{array}$ \\
\hline $\begin{array}{l}\text { Govt. sources for } \\
\text { financial assistance }\end{array}$ & $\begin{array}{c}85 \\
42.3 \% \\
\end{array}$ & $\begin{array}{c}63 \\
30.5 \% \\
\end{array}$ & $\begin{array}{c}60 \\
29.5 \% \\
\end{array}$ & $\begin{array}{c}95 \\
47.5 \% \\
\end{array}$ & $\begin{array}{c}333 \\
41.1 \% \\
\end{array}$ \\
\hline Health, hygiene & $\begin{array}{c}60 \\
29.8 \% \\
\end{array}$ & $\begin{array}{c}59 \\
28.6 \% \\
\end{array}$ & $\begin{array}{c}48 \\
23.6 \% \\
\end{array}$ & $\begin{array}{c}58 \\
29 \% \\
\end{array}$ & $\begin{array}{c}225 \\
27.8 \% \\
\end{array}$ \\
\hline $\begin{array}{l}\text { Various } \\
\text { educational } \\
\text { schemes }\end{array}$ & $\begin{array}{c}59 \\
29.4 \%\end{array}$ & $\begin{array}{c}93 \\
45.1 \%\end{array}$ & $\begin{array}{c}72 \\
34.9 \%\end{array}$ & $\begin{array}{c}64 \\
32 \%\end{array}$ & $\begin{array}{c}288 \\
35.6 \%\end{array}$ \\
\hline Total & 201 & 206 & 203 & 200 & 810 \\
\hline
\end{tabular}


The analysis of the data presented in the Table 11 shows that a large percent (41.1\%) of respondents face difficulty to accessing information about financial assistance from both state and central government agencies and 39.4 per cent for collecting information regarding this. Professionals are also facing the same problem of getting information regarding financial assistance from the government (42.3\%) and to know the bus/train time (34.8\%). Naturally students have the problem of collecting information on various educational schemes and career guidance as well as other job opportunities suitable for them (45.1\%). At the same time labours are facing difficulties accessing information on financial assistance from the government (47.5\%).

\section{Awareness on Various Schemes for Education:-}

Education has become the fundamental need of the people. The people are more concerned about the educational schemes available for their children irrespective of any category, religion, gender etc. In this context the investigator tries to evaluate the awareness status on the various educational schemes for them from the four options. The responses are given in the Table 12.

Table 12:- Awareness on Various Schemes for Education

\begin{tabular}{|l|c|c|c|c|c|}
\hline \multicolumn{1}{|c|}{$\begin{array}{c}\text { Educational } \\
\text { Schemes }\end{array}$} & Professionals & Students & Housewives & Labours & Total \\
\hline Scholarships & 150 & 148 & 119 & 138 & 555 \\
& $74.6 \%$ & $71.8 \%$ & $58.6 \%$ & $69 \%$ & $68.5 \%$ \\
\hline Bus pass & 201 & 206 & 200 & 194 & 801 \\
& $100 \%$ & $100 \%$ & $98.6 \%$ & $97 \%$ & $98.9 \%$ \\
\hline $\begin{array}{l}\text { Institutions and } \\
\text { courses offered by } \\
\text { them }\end{array}$ & 178 & 128 & 98 & 96 & 500 \\
\hline $\begin{array}{l}\text { Different Educational } \\
\text { loans }\end{array}$ & $88.6 \%$ & $62.1 \%$ & $48.3 \%$ & $48 \%$ & $61.7 \%$ \\
\hline
\end{tabular}

It can be clear from the Table 12, that most of the rural people in Kerala are cognizant about the educational schemes facilitated by the government. They mostly prefer the financial assistance available to them; it includes bus charge relaxation permitted to the students (98.9\%). Government of India provides various scholarships for single girl students, students of minority groups and financially backward students etc. There are 68.5 per cent of the rural people under study are conscious about such schemes. Most of the banks are facilitating educational loans for students, the rural people (43.2\%) are not so aware of that.

It can be also seen from the Table12 that majority of the housewives and labours are ignorant about the different educational loans.

\section{Relevance Of Community Information Centres:-}

Community information service assists individuals and groups in daily problem solving and helps to participate in a democratic process, laying emphasis on the needs of those who are unaware and deprived of ready access to the sources of information and assistance. Hence, community information services may be referred as a positive decision to concentrate on enabling people in geographical area, particularly those in lower socio-economic groups in several respects such as housing, employment, family and personal matters, consumer affairs, house- hold finance, civil rights etc.

\section{Desired Information from Community Information Centers:-}

Rural communities face new challenges of information needs for their betterment of life. Agricultural information centres are many in the panchayats of Kerala that disseminate vital information to the farmers about the crop, manure and other related details. However, the rural people who are dependent on professions other than agriculture for livelihood have no such facility that fulfills their information requirements. The investigator tries to identify information needs of rural people which can be fulfilled by a Community Information Centre. 
Table 13:- Desired Information from Community Information Centers

\begin{tabular}{|c|c|c|c|c|c|}
\hline Desired information & Professionals & Students & Housewives & Labours & Total \\
\hline Local news & $\begin{array}{c}158 \\
78.6 \%\end{array}$ & $\begin{array}{c}140 \\
68.0 \%\end{array}$ & $\begin{array}{c}164 \\
80.8 \%\end{array}$ & $\begin{array}{l}172 \\
86 \%\end{array}$ & $\begin{array}{c}634 \\
78.3 \%\end{array}$ \\
\hline $\begin{array}{l}\text { Socially important } \\
\text { current information }\end{array}$ & $\begin{array}{c}147 \\
73.1 \% \\
\end{array}$ & $\begin{array}{c}139 \\
67.5 \% \\
\end{array}$ & $\begin{array}{c}110 \\
54.2 \% \\
\end{array}$ & $\begin{array}{c}129 \\
64.5 \% \\
\end{array}$ & $\begin{array}{c}525 \\
64.8 \% \\
\end{array}$ \\
\hline Various RDP* & $\begin{array}{c}123 \\
15.2 \% \\
\end{array}$ & $\begin{array}{c}87 \\
42.2 \%\end{array}$ & $\begin{array}{c}125 \\
61.6 \% \\
\end{array}$ & $\begin{array}{c}167 \\
83.5 \%\end{array}$ & $\begin{array}{c}502 \\
62.0 \% \\
\end{array}$ \\
\hline Educational programmes & $\begin{array}{c}129 \\
15.9 \% \\
\end{array}$ & $\begin{array}{c}157 \\
76.2 \%\end{array}$ & $\begin{array}{c}95 \\
46.8 \% \\
\end{array}$ & $\begin{array}{c}84 \\
42 \% \\
\end{array}$ & $\begin{array}{c}465 \\
57.4 \% \\
\end{array}$ \\
\hline $\begin{array}{l}\text { Information on job } \\
\text { opportunities in abroad }\end{array}$ & $\begin{array}{c}97 \\
48.3 \%\end{array}$ & $\begin{array}{c}103 \\
50 \%\end{array}$ & $\begin{array}{c}87 \\
42.8 \%\end{array}$ & $\begin{array}{c}53 \\
26.5 \%\end{array}$ & $\begin{array}{c}340 \\
42.0 \%\end{array}$ \\
\hline Govt. policies \&schemes & $\begin{array}{c}106 \\
52.7 \% \\
\end{array}$ & $\begin{array}{c}98 \\
47.6 \% \\
\end{array}$ & $\begin{array}{c}123 \\
60.6 \% \\
\end{array}$ & $\begin{array}{r}138 \\
69 \% \\
\end{array}$ & $\begin{array}{c}465 \\
57.4 \% \\
\end{array}$ \\
\hline Adult education & $\begin{array}{c}63 \\
7.8 \% \\
\end{array}$ & $\begin{array}{c}68 \\
33.0 \% \\
\end{array}$ & $\begin{array}{c}98 \\
35.9 \% \\
\end{array}$ & $\begin{array}{r}140 \\
70 \% \\
\end{array}$ & $\begin{array}{r}369 \\
45.6 \% \\
\end{array}$ \\
\hline Agricultural information & $\begin{array}{c}68 \\
8.4 \%\end{array}$ & $\begin{array}{c}74 \\
35.9 \%\end{array}$ & $\begin{array}{c}81 \\
39.9 \%\end{array}$ & $\begin{array}{l}173 \\
89 \%\end{array}$ & $\begin{array}{c}396 \\
48.8 \%\end{array}$ \\
\hline Total & 201 & 206 & 203 & 200 & 810 \\
\hline
\end{tabular}

*RDP: Rural Development programme

The general analysis of the data presented in the Table 13 makes it clear that the respondents of the study desires to collect local news (78.3\%) followed by socially important current information (64.8\%) and details about various rural development programmes offered to them $(62 \%)$.

The Table 13 also shows that the professionals (78.6\%) and housewives $(80.8 \%)$ under study prefer to collect local news rather than other. The professionals under study would like to acquire socially important information (73.1\%) and government policies and schemes $(52.7 \%)$. Students under study give preference in the order of educational programmes $(76.2 \%)$, local news $(68 \%)$ and socially important current information $(67.5 \%)$. The housewives prefer Rural Development programmes (61.6\%). The labours engaged in the agricultural field wish to collect more information on the agricultural related activities (89\%) and local affairs $(86 \%)$.

The basic needs of citizens such as information, education, entertainment and health services can be addressed through the establishment of Community Information Centres.

\section{Opinion on the Necessity of Community Information Centres:-}

Rural libraries on their part should be proactive by reaching out to potential users rather than passively waiting to be consulted by the few literate users. It should try to reach out to all categories in the community. In the present context, the investigator tries to identify the opinion of the rural people under study on establishing community information centres in their locality.

Table 14:- Opinion on the Necessity of Community Information Centres

\begin{tabular}{|l|c|c|c|c|c|}
\hline \multicolumn{1}{|c|}{ Opinion } & Professionals & Students & Housewives & Labours & Total \\
\hline Necessary & 138 & 99 & 126 & 143 & 506 \\
& $68.7 \%$ & $48.1 \%$ & $62.1 \%$ & $71.5 \%$ & $62.8 \%$ \\
\hline Not necessary & 63 & 107 & 77 & 57 & 304 \\
& $31.3 \%$ & $51.9 \%$ & $37.9 \%$ & $28.5 \%$ & $37.5 \%$ \\
\hline Total & 201 & 206 & 203 & 200 & 810 \\
\hline
\end{tabular}

According to the Table 14 most (62.5\%) of the respondents showed interest in the idea of Community Information Centers and evinced keen interest in developing one such centre in their village. While 37.5 per cent of them felt that the already existing government agencies and information provided on television and radio are more than sufficient. 
Figure 2:- Opinion on the Necessity of Community Information Centres

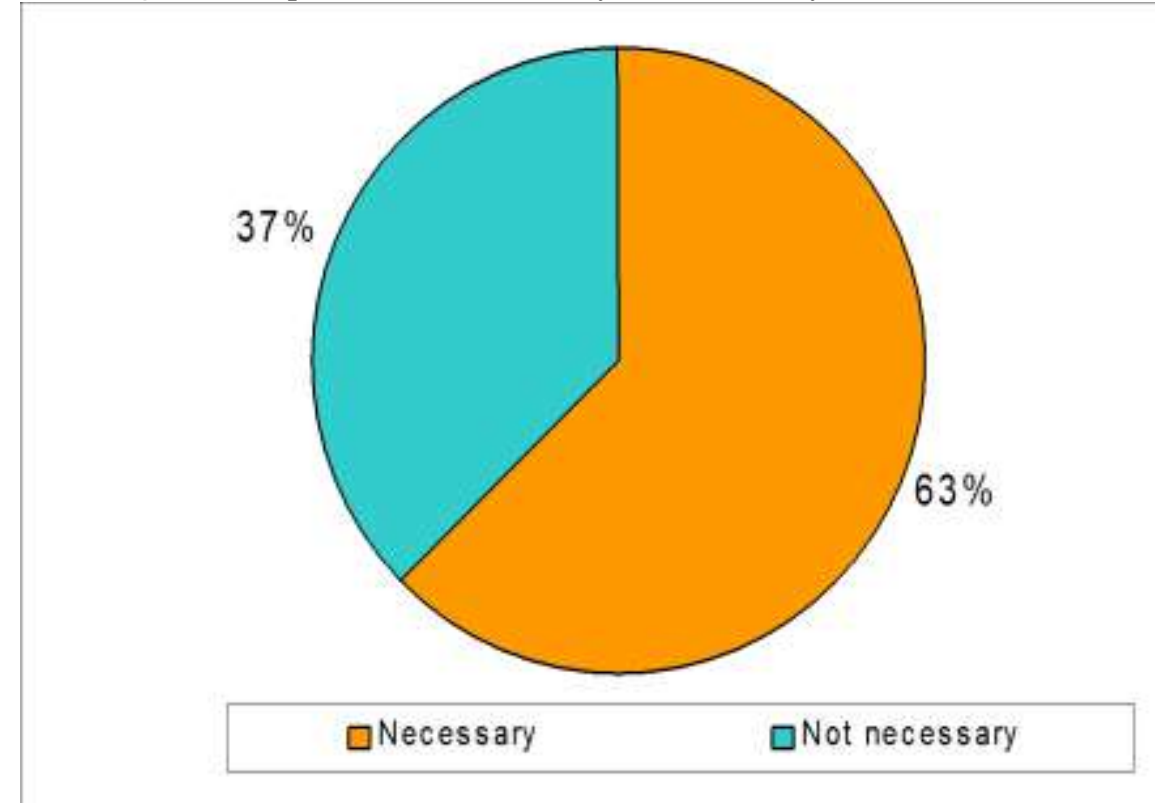

Access to the essential resources for meeting the daily needs of people is the first requisite for maintaining a community and ensuring social well being.

\section{Location Preferred for Community Information Centres:-}

Before setting up community information centre there is a need to consider the approachability for all the people living in that panchayat. The rural people need to answer the question where should the community information centre be located? So as to serve people of that panchayat.

Table 14:- Location Preferred for Community Information Centres

\begin{tabular}{|l|c|c|c|c|c|}
\hline Preferred location & Professionals & Students & Housewives & Labours & Total \\
\hline Panchayat offices & 40 & 35 & 42 & 38 & 155 \\
& $19.9 \%$ & $17.0 \%$ & $20.7 \%$ & $19 \%$ & $19.1 \%$ \\
\hline Agricultural office & 11 & 10 & 14 & 20 & 55 \\
& $5.5 \%$ & $4.8 \%$ & $6.9 \%$ & $10 \%$ & $6.8 \%$ \\
\hline Market & 16 & 24 & 12 & 18 & 70 \\
& $8.0 \%$ & $11.7 \%$ & $5.9 \%$ & $9 \%$ & $8.6 \%$ \\
\hline Local school & 30 & 28 & 27 & 21 & 106 \\
& $14.9 \%$ & $13.6 \%$ & $13.3 \%$ & $10.5 \%$ & $13.1 \%$ \\
\hline Primary health & 3 & 5 & 10 & 15 & 33 \\
centres & $1.5 \%$ & $2.4 \%$ & $4.9 \%$ & $7.5 \%$ & $4.1 \%$ \\
\hline Along with & 3 & 4 & 7 & 6 & 20 \\
temple/church & $1.59 \%$ & $1.9 \%$ & $3.4 \%$ & $3 \%$ & $2.47 \%$ \\
\hline Public library & 38 & 43 & 51 & 30 & 162 \\
& $18.9 \%$ & $20.9 \%$ & $25.1 \%$ & $15 \%$ & $20 \%$ \\
\hline Separate building & 60 & 57 & 40 & 52 & 209 \\
& $29.8 \%$ & $27.6 \%$ & $19.7 \%$ & $26 \%$ & $25.8 \%$ \\
\hline Total & 201 & 206 & 203 & 200 & 810 \\
\hline
\end{tabular}

It can be inferred from the Table 14 that the rural community under study desires to have a separate building $(25.8 \%)$ as information centre which provide necessary information to them. There are 29.8 per cent of the professionals, 27.6 per cent of the students and 26 per cent of the labours voicing having the same opinion. According to 20 per cent of the respondents, public library is the best organization to provide community information services than any other organization and agency. Only a portion (19.1\%) of the people choosing panchayat offices as their community information center. 


\section{Computer with Internet Facility in Community Information Centres:-}

The Community Information Centres should not aim at making their target only literacy minded, but also the culture minded and profession minded. They must help the people to make use of their leisure in a proper manner by providing needful information. The computers and satellites have radically changed the entire life of the world. Communication technology can be used in rural areas by Community Information Centres in many aspects. The investigator tries to identify the opinion of rural people on the necessity of computer in the community information centres.

Table 16:- Computer with Internet Facility in Community Information Centres

\begin{tabular}{|l|c|c|c|c|c|}
\hline $\begin{array}{c}\text { Computer } \\
\text { facility }\end{array}$ & Professionals & Students & Housewives & Labours & Total \\
\hline Necessary & 197 & 185 & 123 & 98 & 601 \\
& $97.1 \%$ & $89.8 \%$ & $60.6 \%$ & $49.0 \%$ & $74.2 \%$ \\
\hline Not necessary & 6 & 21 & 80 & $51.0 \%$ & 209 \\
& $2.9 \%$ & $10.2 \%$ & $39.4 \%$ & 200 & 810 \\
\hline Total & 201 & 206 & 203 & 200 & \\
\hline
\end{tabular}

The Table 16 shows that a large majority of the rural people (74.2\%) under study require computer facility in Community Information Centres. So they get assistance in typing their application, complaint or a memorandum to the government expressing their grievances.

It is also important to note that any single organization cannot provide information to Community information centre on different aspects. There will be need to link community information centres with organizations like state agricultural university, Krishi Bhavans, hospitals, banks, and state development departments. The linkage can be facilitated through computer network if possible or regular visits of representatives of organizations.

\section{Community Information Centres (CIC):-}

Information is so essential that it has become part of every human being. All human beings have the need to information, either individual or collective. It is information transfer and information revolution through which culture exchange, and socio-economic development of a nation is possible. Information is the basic need of life, which helps in the proper fulfillment of other needs such as food, shelter etc. without information the growth and development of any community, is not possible. Therefore, it is the basic responsibility of any welfare government to provide community information centers (Satpathy, 2004) ${ }^{2}$.

\section{Objectives of CICs in general:-}

1. To establish IT infrastructure at the block level

2. To create IT awareness amongst the local populace

3. To provide Internet services such as E-mail and Web access

4. To conduct computer based training programmes

5. To provide Citizen Centric services

6. To provide access to Socio-Economic databases

7. To use IT tools for sustainable regional development

8. Service Facilitation (e-Suvidha) wherein different types of certificates issued by Block and District administrations like SC/ST, Marriage etc. can be disseminated through CICs.

9. Prices and other market information of Agricultural product.

10. Information on Educational opportunities \& Career Counseling.

11. Job portals.

12. Providing the facility of E-edutainment

13. Providing the Internet connectivity to schools, hospitals and post offices in major habitats.

14. Providing distance learning facility to the community.

15. Providing Health care and Telemedicine, E-consulting services.

16. Providing Printing Services (with both DMP \& Laser Printer). ${ }^{3}$

\section{Major findings of the study:-}

1. Kerala people are always keeping their tradition. One among is reading newspapers daily. Hence most preferred source for accessing daily information among rural Kerala is newspapers. Telecommunication and satellite technologies have made television as a household item even in villages. Television along with radio is the 
second most preferable media of getting daily information. This is followed by accessing information from the friends. Libraries unfortunately play a small role for providing daily information. Gender wise analysis shows that male respondents are using newspapers and female are watching television for fulfilling their day to day information needs.

2. On the one hand Kerala has labeled as an information society but on the other hand majority of the rural population is dependent on word of mouth for particular information. Even today main source of information for rural people is friends.

3. The rural community is enjoying most of the information sources available in the present society. According to the study it can be inferred that mass media is the most satisfied information source for rural people in Kerala. Radio and television are also broadcast rural development programmes from which rural people may be aware of alternative for practical life and they can take decisions for their development.

4. The concept of library is still prevailing with the upper class people, or it is restricted to a particular group of people. The rural people mainly visit the library when they cannot fulfill their needs from any other sources. Gender wise analysis of the data shows that majority of the male respondents are visiting library for seeking various kind of information. But majority of the female respondents do not visit library.

5. A large majority of the rural people under study are preferring newspapers than any other reading materials available in the library. Current affairs and literature are the next preferring materials for reading from the library.

6. According to the study majority of the rural men would like to access latest information on various topics, but the rural women under study do not have an urgent need to acquire current information.

7. The rural people under study are answered that they are in need of retrospective information and the remaining have negative opinion.

8. The rural people are selecting their media for collecting information according to their nature of work. The housewives prefer radio because they don't want to spend additional time to listen radio and it will not affect their works. However labours visiting panchayat offices for collecting information on their area of working. Professionals and students are preferring newspapers and television for accessing information for their official and academic purposes.

9. The study that most of the rural people in Kerala are cognizant about the educational schemes facilitated by the government. They mostly prefer the financial assistance available to them; it includes bus charge relaxation permitted to the students. Government of India provides various scholarships for single girl students, students of minority groups and financially backward students etc. there are majority of the rural people under study are conscious about such schemes. Most of the banks are facilitating educational loans for students, the rural people are not so aware of that. It can be also seen from the study that majority of the housewives and labours are ignorant about the different educational loans.

10. The rural people require more information on agriculture and allied fields e.g. animal husbandry, agricultural implements, health and hygiene. Village youth need information on education/occupation environment and government's development programmes and services. Community information centres should cover all these areas. Thus it is quite befitting to think of the community information centres in terms of a source providing variety of information catering to all sectors of the society in order to fulfill such needs.

11. According to the study most of the respondents showed interest in the idea of community information centers and evinced keen interest in developing one such centre in their village. Access to the essential resources for meeting the daily needs of people is the first requisite for maintaining a community and ensuring social well being anywhere.

12. It can be inferred from the study that the rural community under study desires to have a separate building as information centre which provide necessary information to them. Only a small portion of the people has the choice of public library as their community information center. Public library is the best organization to provide community information services than any other organization and agency. There is a general awareness among the villagers in approaching the appropriate authorities to make their demands and express their grievances. In this regard an agency having separate building that can help them in preparing such memorandums is very much needed by the rural people.

13. The study shows that majority of the rural people require computer with internet connectivity in community information centres. The Community Information Centre is a combination of a PC based citizen kiosk with content enabling citizen centric services, E-Governance, E-Learning and E-Commerce. It enables access to databases containing wide range of information regarding agricultural marketing, disaster management, employment opportunities, public health etc. The CICs are supported by effective connectivity. 


\section{Conclusion:-}

The establishment of Community Information Centres (CICs) has been envisaged as a means to use the benefits of Information Technology (IT) to raise the socio-economic conditions of the people of India particularly those in the remote areas of the North Eastern states. This project is planned as a major initiative to utilize IT as a cutting edge tool of development for the state by establishing Community Information Centres. In the present context of the country, when new Information and Communication Technologies are fast emerging and country going ahead with its plans of economic liberalization, there is need to think seriously about making information easily accessible at the door steps of people. In order to meet all the information requirements of village people, well organized information centres in the rural areas of Kerala are necessary. Such Community Information Centres can be social institutes of change and can effectively contribute to the welfare of the rural people (Kumaresan, 2003) ${ }^{4}$.

The developments in Information and Communication Technology are very fast and the considerable changes have been noticed in generation, organization and dissemination of information. This is an age of internet. This network based latest technology, has changed the structure and size of the information centres. Thus benefit of internet, computer and Information Communication Technology can be utilized in setting up the community information centres in our country. These information centres can be networked among the other libraries of the same district, state and lastly with the national centres at the higher level. Among rural communities the awareness of ITs and internet is increasing. The rural people living in any part of the country will be able to use the cellular Information Technology to collect information about weather reports, grain prices, latest harvesting techniques and political developments.

\section{References:-}

1. Raju K A, Social marketing of Rural Development information: a case study, ILA Bulletin, 38(4) (2002) 142144.

2. Satpathy S K, Community information service (CIS) through public libraries; a realistic solution. Information, communication, library and community development. (BR Publications; New Delhi), 2004, p. 363 - 370.

3. Boonalia, Naresh. (1996). An analytical and practical approach to rural library services. Role of libraries in national development. New Delhi: ILA, 130-137.

4. Kumaresan S C, and Chitra Alosia, A study on the need for rural information centers in the villages of Tamil Nadu. Annals of library and information studies, 50 (4) (2003) 137-145.

5. Bajpai, R.P. and Upadhyay, M.P. (2005). Rural development information network: issues and opportunities in India. Library progress (international), 25 (2), 151-155.

6. Sharma, Aravind Kumar. (2007). Information needs and sharing pattern among rural women; a study. IASLIC Bulletin, 52 (3), 159-167.

7. http://keala.gov.in>census 2011 . 